\title{
ASPECTS OF THE GLACIOLOGY OF MEIGHEN ISLAND, NORTHWEST TERRITORIES, CANADA
}

\author{
By K. C. Arnold \\ (Department of Mines and Technical Surveys, Geographical Branch, Ottawa, Canada)
}

Abstract. Meighen Island lies in the centre of the north coast of the Queen Elizabeth Islands and fronts on the Arctic Ocean. An ice cap of about $76 \mathrm{~km} .^{2}$ covers about one-tenth of the island. Its greatest thickness of ${ }_{1} 50 \mathrm{~m}$. occurs under the summit, near the south end, which was $268 \mathrm{~m}$. above sea-level in 1960 . The northern half of the ice cap is less than $30 \mathrm{~m}$. thick; and the total volume is of the order of $2,000 \times 10^{6} \mathrm{~m} .3$.

Precipitation is low in the northern Queen Elizabeth Islands, and Meighen Island lies in an area where summer temperatures are lowest. In the winters of $1959-60,1960-61$ and $1961-62$, the snow accumulation was $12 \cdot 6,1^{8} \cdot 2$ and $1_{4} \cdot 1 \mathrm{~cm}$. of water equivalent. Some snowfall remained on the higher part of the ice cap in the cold summer of $196 \mathrm{I}$; but the ice cap diminished in volume in each year; by $36 \times 10^{6}, 72 \times 10^{6}$, $22 \times 10^{6}$ and $91 \times 10^{6} \mathrm{~m} .3$ in the $1959,1960,1961$ and 1962 ablation seasons.

If the conditions of these four seasons were maintained the ice cap would disappear in about $100 \mathrm{yr}$. However, a radio-carbon dating of a saxifrage exposed by the retreat of the ice from a small nunatak near the northern edge gave a date of less than $100 \mathrm{yr}$, , and it appears that the existence of the ice cap might be sensitively related to recent climatic change.

Careful surveys were made in 1959,1960 and 1961 in an attempt to detect movement in the ice cap. Unequivocal evidence is not available from these surveys; but the stake network has been maintained and another survey has recently been completed.

RÉsumé. Aspects de la glaciologie dans l'île Meighen ( $T$. du N.-O.). Située au centre de la côte nord des iles de la Reine-Elisabeth, l'île Meighen fait face à l'océan Arctique. Elle est recouverte, sur environ un dizième de sa surface, d'une calotte glaciaire de quelque 76 kilomètres carrés. La glace atteint sa plus grande épaisseur ( 150 mètres) sous le point culminant, près de l'extrémité sud, et dont l'altitude était de 268 mètres en 1960. Dans la moitié nord de la calotte, la glace a moins de 30 mètres d'épaisseur. La calotte contient à peu près $2000 \times 10^{6}$ mètres cubes de glace.

La précipitation est faible dans la partie nord des îles de la Reine-Elisabeth, et l'île Meighen se trouve dans une région où les températures d'été sont les plus basses. Au cours des hivers 1959-60, 1960-6 i et $1961-62$, la couche de neige accumulée équivalait à $12,6,18,2$ et 14,1 centimètres d'eau. Il en restait un peu sur la partic supérieure de la calotte durant l'été froid de $196 \mathrm{I}$. Mais au cours des saisons d'ablation (évaporation et fusion de la glace) de 1959, r 1960, r961 et 1962, le volume de la calotte a diminué, successivement, de $36 \times 10^{6}$, de $72 \times 10^{6}$, de $22 \times 10^{6}$ et de $91 \times 10^{6}$ mètres cubes.

$\mathrm{Si}$ ce r gime d'ablation se continuait, la calotte disparaîtrait en un siècle environ. Cependant, on a fait la radiodatation au carbone 14 d'une saxifrage mise à nu après le retrait de la glace d'un petit nunatak proche de la bordure nord: on a constaté ainsi que la glace date de moins d'un siècle, et il semble que l'existence mème de la calotte puisse se rattacher sensiblement à une modification réccnte du climat.

Afin de déterminer le mouvement de la glace de la calotte, on a fait des relevés minutieux en 1959,1960 et 1961. Les résultats ainsi obtenus ne sont pas tout à fait probants, mais on a maintenu le réseau de piquets et l'on a récemment achevé un autre relevé.

Zusammenfassung. Zur Glaziologie von Meighen Island, Nordwestterritorien, Canada. Meighen Island liegt in der Mitte des Nordrandes der Königin-Elisabeth-Inselgruppe und stösst an das Nördliche Eismeer. Etwa ein Zehntel der Insel ist von einer ungefähr $76 \mathrm{~km}^{2}$ grossen Eishaube bedeckt. Ihre grösste Dicke von $150 \mathrm{~m}$ hat sie unter dem Gipfel, nahe ihrem südlichen Ende, das im Jahre $1960268 \mathrm{~m}$ über dem Meeresspiegel lag. Die nördliche Hälfte der Eishaube ist kaum $30 \mathrm{~m}$ dick; ihr gesamter Rauminhalt ist von der Grössenordnung
$2000 \times 10^{6} \mathrm{~m}^{3}$.

In $\mathrm{n}$ ̈̈rdlichen Teil der Königin-Elisabeth-Inselgruppe ist die Niederschlagshöhe gering, und Meighen Island liegt in einem Gebiet, wo die Sommertemperaturen am niedrigsten sind. In den Wintern 1959-6o, $1960-61$ und $1961-62$ betrug der Wasserwert der Schneeablagerung 12,6, 18,2 und $14,1 \mathrm{~cm}$. In dem kühlen Sommer 1961 blieb auf dem höheren Teil der Eishaube der Schnee teilweise liegen; aber das Volumen der Eishaube verringerte sich von.Jahr zu Jahr, und zwar in den Abschmelzzeiten $1959,1960,1961$ und 1962
um $36 \times 10^{6}, 72 \times 10^{6}, 22 \times 10^{6}$ und $91 \times 10^{6} \mathrm{~m}^{3}$.

Wenn die Verhältnisse weiter die gleichen blieben wie in diesen vier Abschmelzzeiten, so würde die Eishaube in etwa 100 Jahren verschwinden. Dis Radiokarbon-Altersbestimmung einer beim Rückgang des Eises von einem kleinen Nunatak am Nordrande blossgelegten Saxifraga ergab jedoch weniger als 100 Jahre, und so scheint es, dass die Existenz der Eishaube mit jüngeren klimatischen Veränderungen aufs engste
in Verbindung steht.

In den Jahren 1959,1960 und 1961 wurden sorgfältige Vermessungen durchgeführt, um eine etwaige Bewegung in der Eishaube festzustellen. Eindeutige Beweise blieben zunächst aus; aber die Vermessungspfähle wurden stehen gelassen und kürzlich fand aufs neue eine Vermessung statt. 


\section{INTRODUCTION}

The Queen Elizabeth Islands form the most northerly part of the Canadian Arctic Archipelago. Their southern extent is bounded by Lancaster Sound, leading to Baffin Bay; and Viscount Melville Sound, leading to the Beaufort Sea. These islands were the focus of many expeditions in the nineteenth century, and the last discoveries of new land were made as late as 1916. An increase of interest in the islands dates from April 1947, when a weather station was set up at Eureka, followed by stations at Resolute Bay, Isachsen and Mould Bay, and Alert. These stations served as bases for scientific investigations in the islands. Since I959, the Polar Continental Shelf Project has worked in this area and over the continental shelf off the islands. The first main base was at the Isachsen weather station (lat. $78^{\circ} 47^{\prime} \mathrm{N}$., long. I0 $3^{\circ} 23^{\prime}$ W.).

The eastern part of the Queen Elizabeth Islands is mountainous, and heavily glacierized; the western islands are lower, and, but for two exceptions, without an ice cover. In south-west Melville Island a dissected plateau rises to over 2,000 ft. (6ro m.), and four small ice caps occur here; and Meighen Island, 30 miles $(48 \mathrm{~km}$.) to the west of Axel Heiberg Island, also has a small ice cap.

On the Glacial map of Canada, ${ }^{*}$ the area between the ice caps of Melville and Meighen Islands is shown as unglaciated, as there was no definite evidence of the destructive or constructive effects of a continental glaciation. The geology of the area consists of relatively unresistant rocks of Mesozoic age, and of unconsolidated sands and gravels of late Tertiary age. In the latter formation wind erosion and periglacial process could quickly obscure the small-scale features of glaciation. Ice rafting is a possible explanation of the occurrence of erratic boulders over much of the area.

Savile ( $196 \mathrm{I}$ ) has pointed out that, because of the poor flora and the low summer temperatures presently experienced in the area, it could hardly have been without a permanent snow cover with a general lowering of temperature, even allowing for the very scanty precipitation prevailing in these islands. This discussion gives added interest to the state of the small ice cap on Meighen Island.

\section{Air Photography}

Meighen Island lies in the centre of the north-west edge of the Queen Elizabeth Islands, and just to the north-east of the area shown as unglaciated on the Glacial map of Canada. From its even sky line, Stefansson (192 I, ch. li, p. 518), who discovered the island in r916, deduced that it had an ice cap, and this was confirmed by flights after I 945 . What is believed to be the first air photograph of the island was taken on 15 August 1946; it appears in Arctic Canada from the air (Dunbar and Greenaway, 1956, p. 359). Some fresh snow lies on the higher parts of the ice cap. Details of the edge are not sufficiently clear to enable much to be said about recession from 1946 to 1950 , when the island was re-photographed on 8 July (Fig. I). The vertical photographs of the trimetrogon photography cover the west part of the ice cap; some recession seems to have taken place in valleys leading from its south-west edge.

Vertical photography from $30,000 \mathrm{ft}$. (9, I $40 \mathrm{~m}$.) taken on 5 August 1959 provides evidence of recession for the period $195^{0}-59$. The ice cap was wasting slowly during this period. The most rapid changes were in valleys at the south-west and south-east edges, and at the northern tongue, where the thinning of the ice exposed some nunataks. The most recent photography was taken on 15 August 1960; it is being used to plot a I : 25,000 map of the ice cap with a $10 \mathrm{~m}$. contour interval. The 1960 photography shows continued recession, and an increase in the number and size of the nunataks exposed by the thinning of the ice.

* Geological Association of Canada. 1958. 1 : 3,80 1,600. 


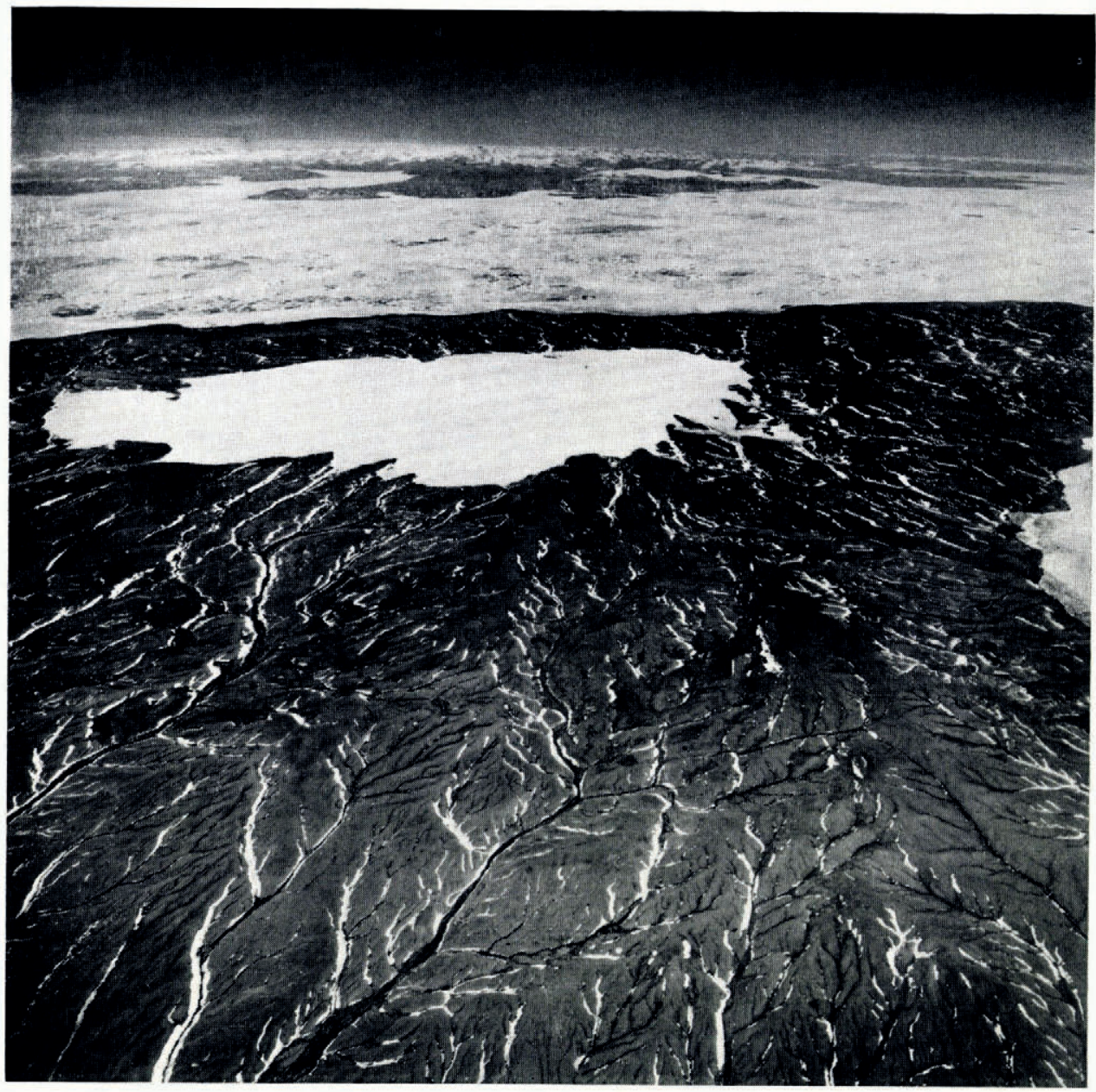

Fig. I. Meighen Island ice cap, looking east, with Sverdrup Channel and Axel Heiberg Island in the background, 18.74 uly 1950 (Royal Canadian Air Force air photograph)

R. Thorsteinsson (I96I, p. I6-I7) was the first to visit the ice cap, on 3 June I957. G. Hattersley-Smith, commenting on his observations, pointed out that the ice cap was thinning because of its low elevation and the cryoconite holes containing wind-blown dust found on it.

The observations discussed in this paper were begun in 1959 when a party was on the ice cap from 8 July to 4 August. Ablation stakes were set up over the southern section and their positions were carefully surveyed. In the 1960 season the stake network was extended over the whole ice cap, and in 1960 , I96r and ig62 a party was in the field for most of the months of June, July and August (Fig. 2).

\section{Depth from Gravity Observations}

In the r 960 season the depth of the ice cap was determined by gravity observations made by R. Hornal of the Dominion Observatories Branch (Fig. 3). These observations show that the greatest depth of $5^{\circ} \mathrm{m}$. occurs under the summit, which was $268 \mathrm{~m}$. (878 ft.) above sealevel in 1960. 
The northern half of the ice cap is less than $30 \mathrm{~m}$. thick and the northern tongue varies between ro to $5 \mathrm{~m}$. Hornal (unpublished) estimates the reliability of his calculations to be $\pm \mathrm{I} 5 \mathrm{~m}$. A seismic party worked on the ice cap for a short while in r 960 and, although the nature of the under surface was not conducive to clear reflcctions, their results supported Hornal's calculations (personal communication from C. D. Hobson).

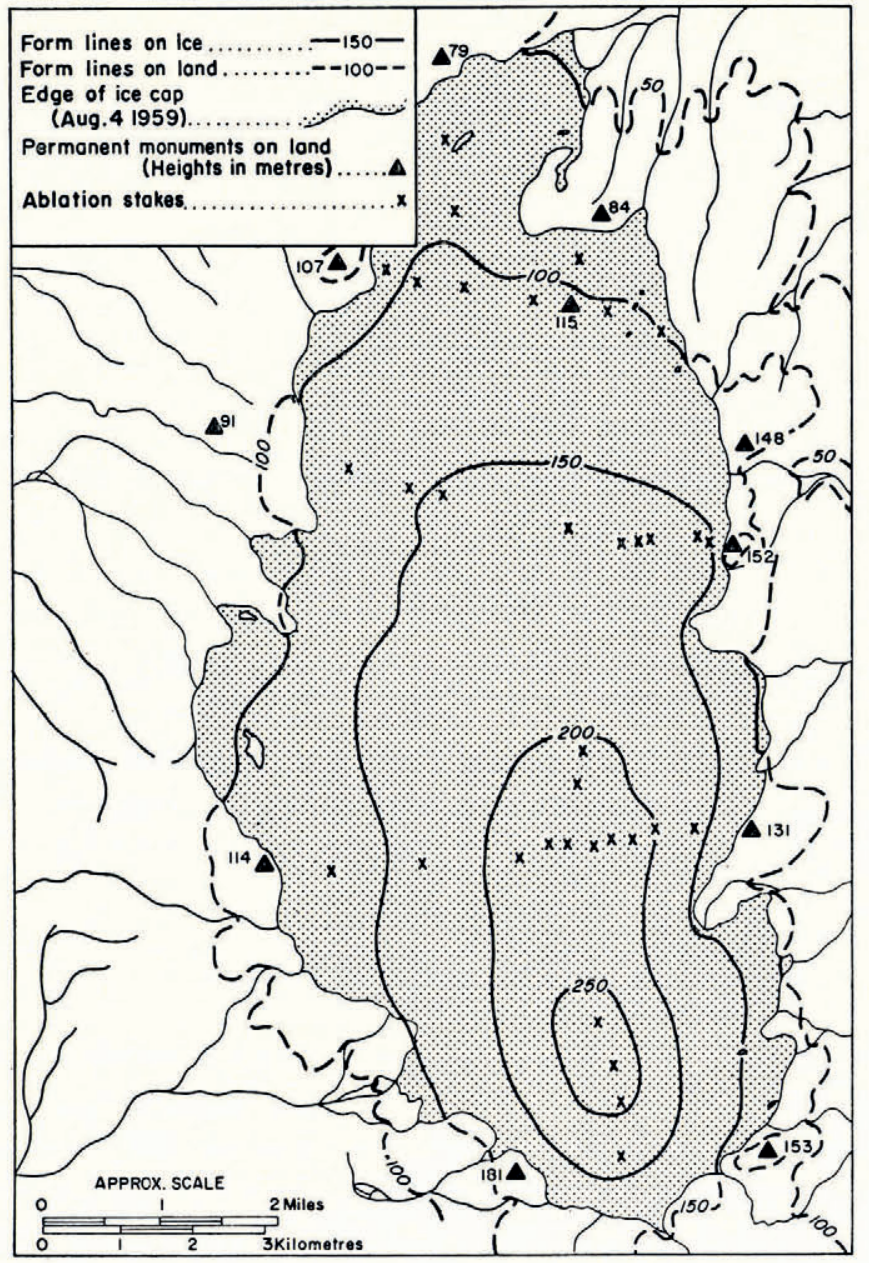

Fig. 2. Sketch map of Meighen Island ice cap, based on air photography taken 5 August 1959

The ice cap, by a rough estimate from the latest air photographs, is $76 \mathrm{~km} .{ }^{2}(28 \mathrm{sq}$. miles) in extent and covers about one-tenth of the island. Using Hornal's depth measurements, an estimate of the volume of the ice cap is $2,000 \times 10^{6} \mathrm{~m} .^{3}$ of ice or about $1,800 \times 10^{6} \mathrm{~m} .{ }^{3}$ of water equivalent. The accumulation and ablation measurements can be related to these figures.

\section{Accumulation}

In I960, I961 and I 962 the winter's snow accumulation was measured at each stake before the melt season began (Fig. 4). In I 960 and r96r there were 36 stakes but one was lost in 

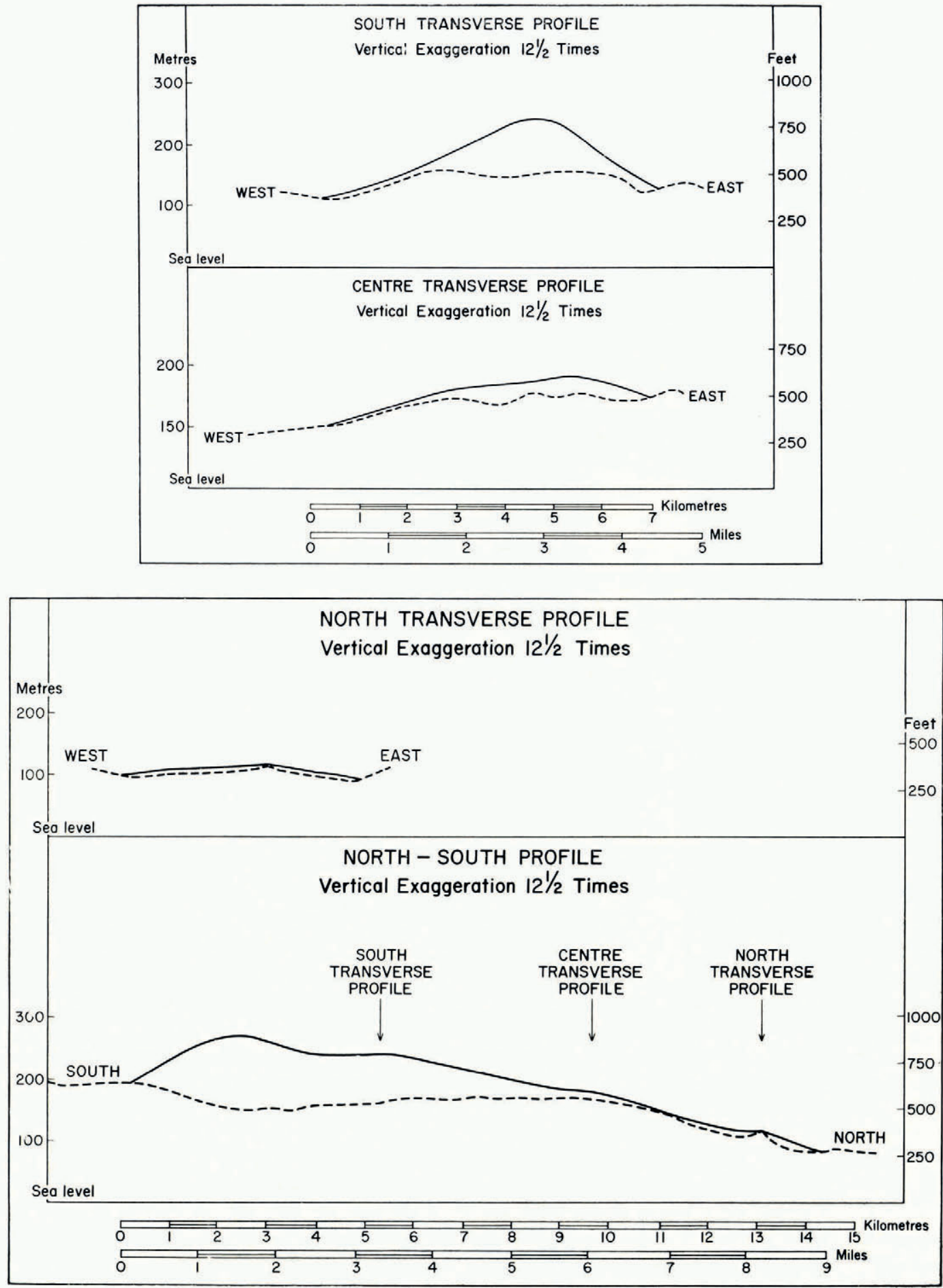

Fig. 3. Depth profiles from gravity observations by R. Hornal, Dominion Observatories Branch, Ottawa 


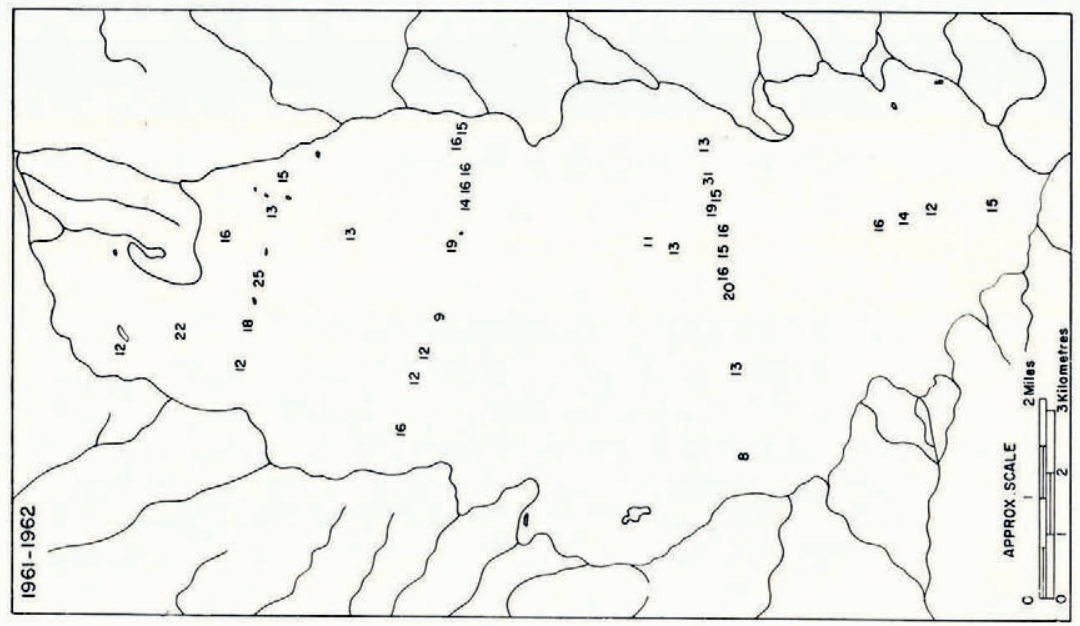

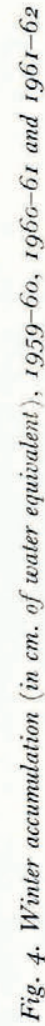
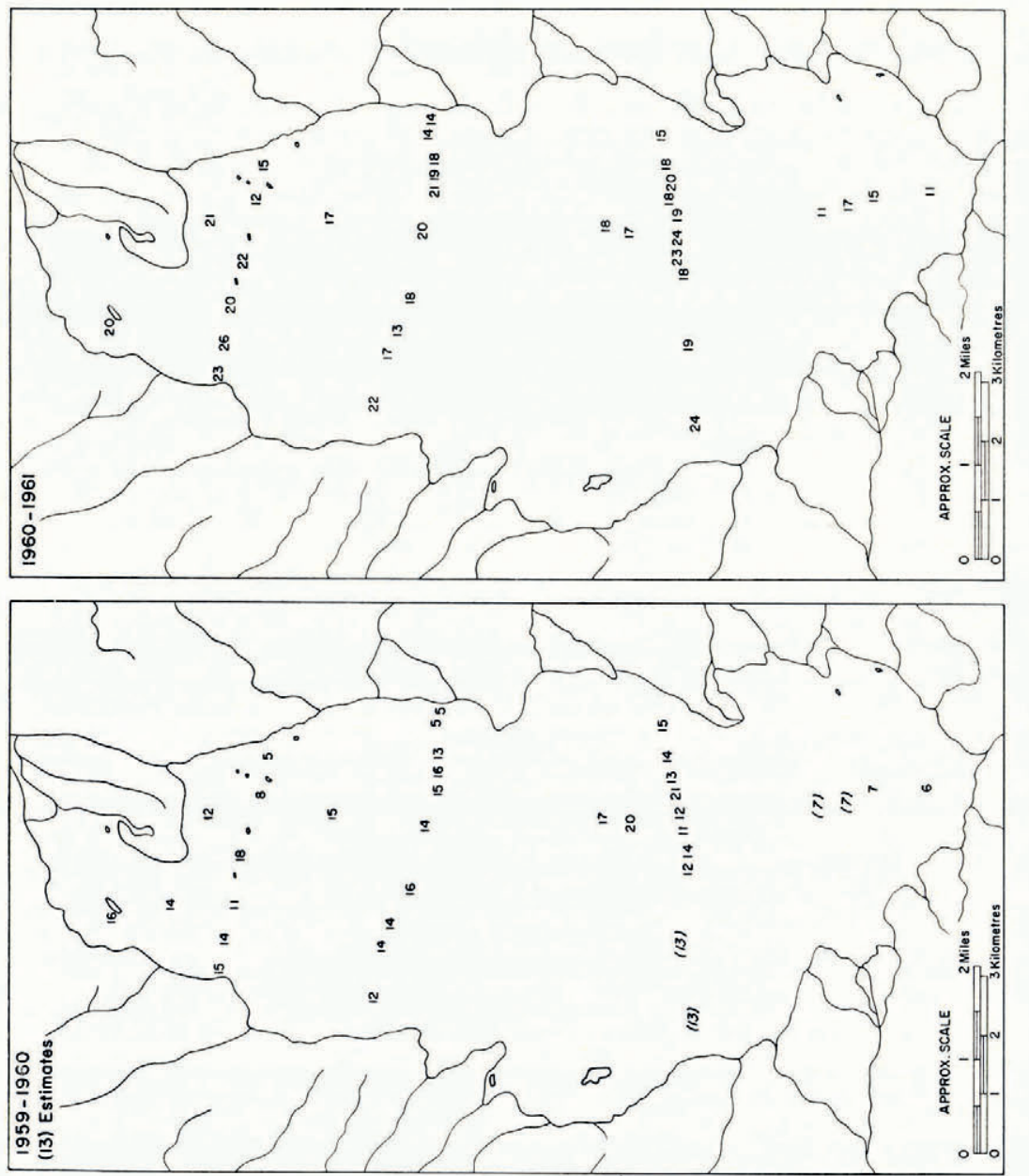
August I96 I because of the rapid retreat of the north end of the ice cap. Apart from this, the measurements were made at identical sites from year to year. At least ten measurements of snow depth were made at each stake and vertical profiles of density were made at intervals along the profile. In $196 \mathrm{I}$ density varied from $0.32 \mathrm{~g} . / \mathrm{cm} .^{3}$ at the top of the ice cap to 0.39 g. $/ \mathrm{cm} .^{3}$ at the sides. In 1962 the lowest value was $0.32 \mathrm{~g} . / \mathrm{cm} .{ }^{3}$ but, as there had been some melting on the northern tongue of the ice cap, the highest value was $0 \cdot 49 \mathrm{~g} . / \mathrm{cm} .{ }^{3}$. The median value in ${ }_{196} \mathrm{I}$ was $0.35 \mathrm{~g} . / \mathrm{cm} .{ }^{3}$ and in 1962 it was $0.3^{8} \mathrm{~g} . / \mathrm{cm} .^{3}$. Vertical sampling was not used in 1960 ; as the state of the snow was very similar to that in $196 \mathrm{r}$, the $196 \mathrm{r}$ values of snow density have been used to calculate the water equivalent for that year.

The distribution of stakes over the ice cap is not an even one, as it was partly dictated by the requirements of the survey control. In an attempt to assess the effect of the irregular distribution of stakes, a Thiessen diagram was drawn by connecting the median lines between the stakes. The percentage of the ice cap represented by each stake was calculated and this varied from a high of 8.6 per cent to a low of 0.4 per cent. The snowfall from each stake was weighted in this proportion and gave the following water equivalents $(\mathrm{cm}$.) for the whole ice cap:

$\begin{array}{ccc} & \text { Unweighted mean } & \text { Weighted mean } \\ 1959-60 & 12 \cdot 7 & 12 \cdot 6 \\ 1960-61 & 18 \cdot 4 & 18 \cdot 2 \\ 1961-62 & 15 \cdot 2 & 14 \cdot 1\end{array}$

The close correspondence between the weighted and unweighted means suggests that the snowfall was evenly distributed over the ice cap and that the sampling method was sound. The standard deviation in water equivalent for each year is about $3 \mathrm{~cm}$.

The accumulation for $1962-63$ was measured at the same stakes by W. S. Paterson (personal communication) and gave an unweighted mean of $20.3 \mathrm{~cm}$. (weighted mean, $19.4 \mathrm{~cm}$.) of water equivalent. The records of precipitation and depth of snow on the ground at Isachsen and Eureka have been reviewed, but there appears to be no relationship with accumulation at Meighen Island. As some snow was still lying on the upper parts of the ice cap in July 1959, and the depth of snow on the ground was somewhat above average at Eureka in that year, an estimate of $18 \mathrm{~cm}$. is made for the water equivalent of the $195^{8-} 59$ winter. The winter accumulation has been, therefore:

\begin{tabular}{cccc} 
& \multicolumn{3}{c}{ Ice cap gained } \\
$1958-59$ & $\mathrm{~cm}$. water equivalent & $\mathrm{m} .3$ water equivalent & $\mathrm{m} .3$ ice \\
$1959-60$ & $(18)$ & $\left(14 \times 10^{6}\right)$ & $\left(15.5 \times 10^{6}\right)$ \\
$1960-61$ & 12.6 & $9.6 \times 10^{6}$ & $10.6 \times 10^{6}$ \\
$1961-62$ & $18 \cdot 2$ & $13.8 \times 10^{6}$ & $15.3 \times 10^{6}$ \\
$1962-63$ & 14.1 & $10.7 \times 10^{6}$ & $11.9 \times 10^{6}$ \\
1962.4 & $14.7 \times 10^{6}$ & $16.3 \times 10^{6}$
\end{tabular}

Some snow fell during the ablation season, after the accumulation measurements had been made. The weather observations were taken at the main camp, which was about $2.4 \mathrm{~km}$. ( $\mathrm{I} .5 \mathrm{miles}$ ) north of the summit of the ice cap, at $240 \mathrm{~m}$. (79o ft.) above sea-level. The water equivalent of the summer snow was $0.6 \mathrm{~cm}$. in $196 \mathrm{I}$ and $0.1 \mathrm{~cm}$. in 1962 ; and it is of small importance in comparison with the winter accumulation. The weather observations in I960 were taken at irregular intervals and give only 45 per cent of a complete 3-hourly record. Snow fell on only three days during the ablation season and its amount is probably close to that of the 1962 season.

Rain falling on the higher parts of the ice cap may not drain away in a cold summer and can play a role in the formation of superimposed ice. This was a factor in $196 \mathrm{I}$ when $8.5 \mathrm{~cm}$. of rain fell during the ablation season. Snow lay on the upper part of the ice cap throughout the summer and, taking this area into account, the summer rain added about $\mathrm{I} \mathrm{cm}$. of water equivalent to the total accumulation during the r960-6i budget year. In r959 and i96 r rime 
often formed on the upper part of the ice cap but it rapidly disappeared with a change in weather conditions. It probably makes a very small contribution to the accumulation.

\section{Ablation}

Ablation measurements were made at approximately weekly intervals in the $1960,196 \mathrm{r}$ and 1962 seasons (Fig. 5). In ig6o and 1962 all the winter's snowfall was lost but in 196r some snow remained on the higher part of the ice cap and, becoming soaked with rainfall and melt water, formed a layer of superimposed ice. The network of stakes only covered the southern part of the ice cap in I 959 but, by extrapolating on the basis of the ablation of the northern part of the ice cap in the three later seasons, an estimate can be made for the loss of ice from the whole ice cap in that year. The net loss of ice for the four years was:

\begin{tabular}{cccc} 
& \multicolumn{2}{c}{ Net ablation } \\
$\mathrm{m} .3^{3}$ water equivalent & water equivalent/unit area \\
1959 & $\left(36 \times 10^{6}\right)$ & $\left(32 \times 10^{6}\right)$ & $(42 \mathrm{~cm})$. \\
1960 & $72 \times 10^{6}$ & $65 \times 10^{6}$ & $85 \mathrm{~cm}$. \\
1961 & $22 \times 10^{6}$ & $20 \times 10^{6}$ & $26 \mathrm{~cm}$. \\
1962 & $91 \times 10^{6}$ & $82 \times 10^{6}$ & $108 \mathrm{~cm}$.
\end{tabular}

(brackets indicate estimate)

The gross ablation for the four budget years would be:

\begin{tabular}{|c|c|c|c|c|}
\hline & 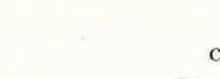 & $\begin{array}{l}\text { Gross ablation } \\
\text { f water equir }\end{array}$ & & \\
\hline & Accu & iion & Net ablation & Gross ablation \\
\hline & $\begin{array}{c}\text { In accumulation } \\
\text { season }\end{array}$ & $\begin{array}{l}\text { In ablation } \\
\text { season }\end{array}$ & & \\
\hline I $95^{8-59}$ & $(18)$ & (I) & $(42)$ & $(6 \mathrm{I})$ \\
\hline I $959-60$ & 13 & (o) & 85 & 98 \\
\hline $1960-61$ & I8 & 2 & 26 & $4^{6}$ \\
\hline I $96 \mathrm{I}-62$ & 14 & o & 108 & 122 \\
\hline
\end{tabular}

Gross ablation showed a strong negative correlation with height. In 1962 the correlation $(r=-0 \cdot 73)$ was significant at the I per cent level for those stakes with an uninterrupted record. Gross ablation against distance from the edge (which itself is related to height) was also tested and gave an $r$ value of -0.63 .

July of 1962 was a month with unusually clear skies and light winds, and the influence of radiation was clearly dominant in that year. This is reflected in the smaller contrast between the amount of ice melted off the top of the ice cap compared with the sides. A micrometeorological study made in I 96 I by Stebelsky (unpublished) suggests that the air reaching Meighen Island from the ice-covered seas surrounding it has little opportunity to be warmed before reaching the ice cap, and that the melting effect does not extend very far in from the edge of the ice. Conversely, its cooling effect upon the surrounding land is limited and is most evident in relatively calm conditions when colder air flows down the river valleys leading from the ice cap. The relatively poor flora in the valleys, compared with the interfluves, may be subsidiary evidence for this.

\section{Temperatures}

In I961 and i962, well-calibrated thermograph records were maintained at the ice cap station (Arnold and MacKay, in press). These give a good estimate of melting degree-day 

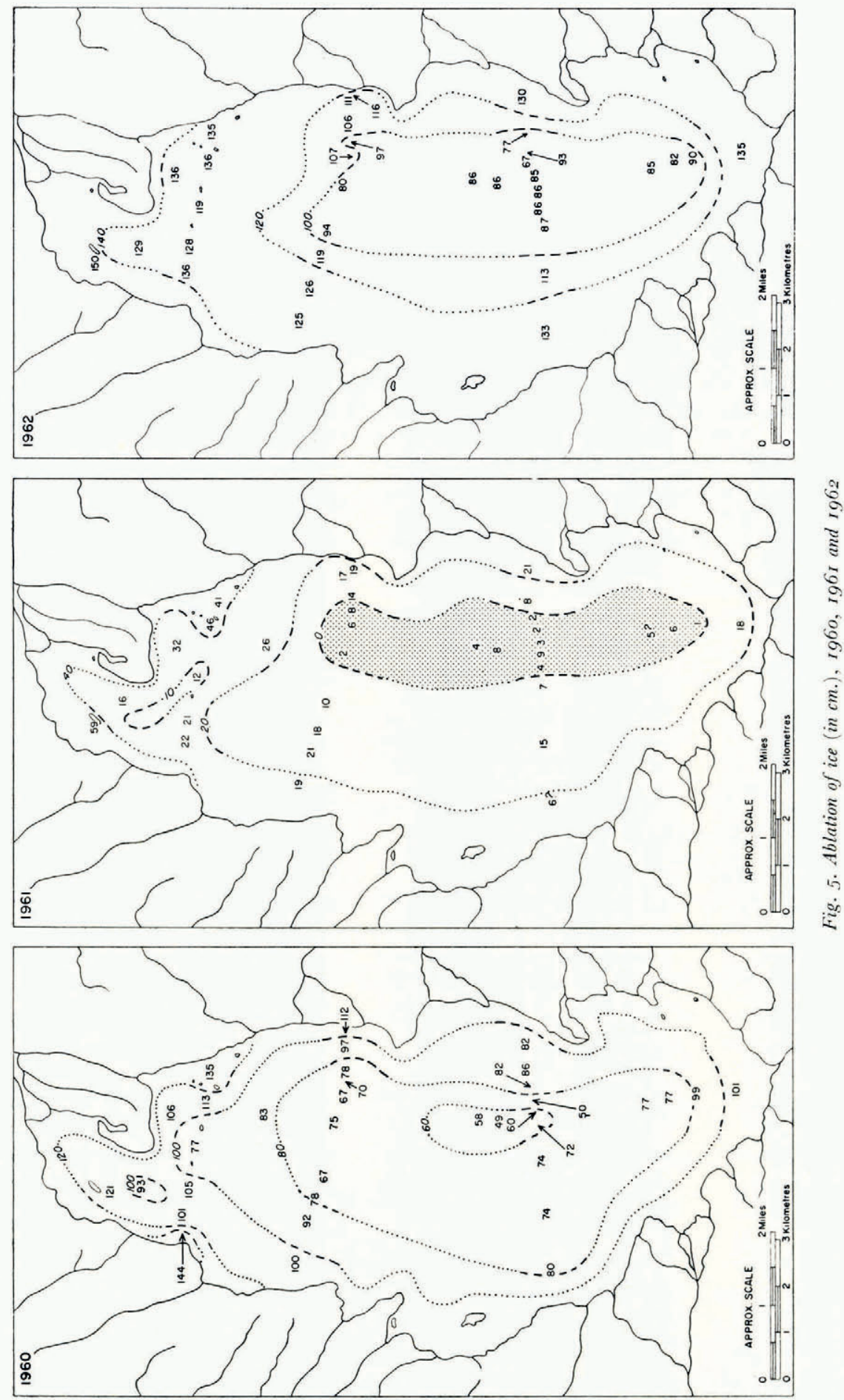
totals. In 1960 trouble with the thermograph gave an interrupted record and the degree-day total estimated from the mean daily temperatures is probably too high. The relation between gross ablation and degree-day totals was:

$\begin{array}{ccc} & \begin{array}{c}\text { Gross ablation } \\ \text { cm. of water equivalent }\end{array} & \text { Melting degree days } \\ & { }^{\circ} \mathrm{F} . \\ 1960 & 98 & 224 \\ 196 \mathrm{I} & 46 & 84 \\ 1962 & 122 & 214\end{array}$

A good correlation of mean daily temperatures exists between the Meighen Island ice cap station and the Isachsen Joint Arctic weather station (MacKay and Arnold, unpublished). The median value for nine comparable intervals (six full months and three partial months) was 0.83 with a range of 0.94 to 0.47 . The lowest value was for the month of July I960, when the ice cap station had 23 days with fog, compared with 6 days at Isachsen.

The following table lists the mean temperatures in degrees Fahrenheit for June, July and August for the Isachsen and Eureka weather stations since they were established:

\begin{tabular}{|c|c|c|c|c|c|c|}
\hline & June & $\begin{array}{c}\text { Isachsen } \\
\text { fuly }\end{array}$ & August & June & $\begin{array}{c}\text { Eureka } \\
\text { fuly }\end{array}$ & August \\
\hline I947 & - & - & - & - & $4^{2}$ & \\
\hline I 948 & 30 & $3^{8}$ & $3^{I}$ & $3^{8}$ & 43 & $3^{8}$ \\
\hline I949 & $3^{1}$ & 37 & 37 & 39 & 43 & 38 \\
\hline $195^{\circ}$ & 30 & $3^{8}$ & 33 & 36 & 43 & $3^{8}$ \\
\hline $195^{I}$ & $3^{2}$ & 39 & 34 & 37 & $4^{2}$ & 37 \\
\hline 1952 & 33 & $4^{\circ}$ & 32 & 39 & 44 & $3^{8}$ \\
\hline I953 & $3^{I}$ & 35 & $3 \mathrm{I}$ & 35 & 39 & 33 \\
\hline I954 & $3^{2}$ & $3^{8}$ & 36 & $3^{8}$ & $4^{2}$ & $4^{\circ}$ \\
\hline 1955 & 30 & 34 & 34 & 34 & 39 & 38 \\
\hline 1956 & 28 & 36 & $3^{I}$ & 33 & $4^{\circ}$ & $3^{8}$ \\
\hline I957 & 33 & $4^{2}$ & 43 & 40 & $4^{2}$ & 37 \\
\hline I $95^{8}$ & $3^{2}$ & $4^{I}$ & 40 & 36 & $4^{2}$ & $4^{\circ}$ \\
\hline I959 & 30 & 43 & 36 & 34 & 43 & $4^{I}$ \\
\hline 196o & 33 & $3^{8}$ & $3^{8}$ & 40 & 44 & 43 \\
\hline 1961 & 29 & 34 & 33 & 32 & 40 & 35 \\
\hline 1962 & 34 & 44 & 33 & $3^{8}$ & 45 & 39 \\
\hline
\end{tabular}

This table shows that the summers of $196 \mathrm{I}$ and 1962 were representative of the coldest and warmest summers since these stations were set up. The corresponding means for the Meighen Island ice cap station are (full months of record only):

$\begin{array}{lccc} & \text { June } & \text { July } & \text { August } \\ 1960 & - & 34 & 34 \\ 1961 & 25 & 32 & 28 \\ 1962 & - & 37 & -\end{array}$

\section{Commentary}

These means indicate that, if the accumulation measured at Meighen Island in I96o, I96 I and 1962 is representative of the $15 \mathrm{yr}$. period represented by the Isachsen and Eureka monthly mean temperatures, the ice cap would have lost in volume in each year. Using the southern transverse profile of ice thickness as a representative section, an attempt has been made to estimate the expected life of the ice cap. If the I96o, I961 and I962 rates of net ablation at the top, middle and edge of the section are averaged and extrapolated for io yr. intervals, an ice cap of increasing steepness would have a core with an expected life of a little over 100 yr. Such a simple case would not occur, and the diagram was primarily drawn to assess the effect of increasing surface slope on the possibility of movement in the ice cap. A more realistic model is to assume that, as the ice cap thins, the rate of ice loss at the top of the section approaches that at the sides. This would give an expected life of go to roo yr. This estimate should be used with caution, as we have no knowledge of a long-term average of 
accumulation. Indeed, the difference between the I950 and 1959 air photography suggests that the ice cap would have a considerably longer life, and that the 1960,1961 and 1962 accumulation measurements are below the recent average.

In I96I a well-developed saxifrage was exposed on the edge of a small nunatak near the tongue of the ice cap. The top of this nunatak first appeared in 1960 and the plant was covered by at least $\mathrm{I} \cdot 4 \mathrm{~m}$. of ice at that time. A radio-carbon dating of this plant gave an age of less than $100 \mathrm{yr}$. If this date is reliable, it would indicate relatively recent fluctuations of the northern tongue which Hornal showed to be very thin. A pollen analysis by J. Terasmae, Geological Survey of Canada, suggested that the plant mat melting out from beneath the ice cap contains sub-recent pollen that disappears in a few years, probably because of oxidation, and is later replaced by fossil pollen and spores from the underlying beds.

The greatest former extent of the ice cap, as indicated by stream patterns, appears to be at its north end. However, pond shorelines and ice-margin streams occur in the presently icefree southern part of the island. Because of the fresh appearance of these features, and considering the unconsolidated nature of the sands and gravels in which they occur, a recent ice cover, not necessarily joined to the present ice cap, is a possibility. In this regard, it is interesting that F. A. Cook described the first land that he met on his return from his controversial discovery of the North Pole in 1908 as being partly ice-covered. Cook thought that this was Amund Ringnes Island, and Stefansson (1939, p. 310) points out that Isachsen made no mention of an ice cap here when he discovered the island in I9or. Cook's accounts of his travels are generally regarded as being liberally spiced with fiction but it is just possible that this disparity was a real one.

On the very rough basis of three years' measurements, if the winter accumulation remained at about $15 \mathrm{~cm}$. of water equivalent, a drop in Isachsen mean summer temperatures (June, July and August) of about $5^{\circ} \mathrm{F} .\left(2 \cdot 8^{\circ} \mathrm{C}\right.$. $)$ would suffice to give the ice cap a positive budget. If the temperature remained at the $1948-62$ Isachsen summer mean, an increase in accumulation from 15 to about $90 \mathrm{~cm}$. of water equivalent would have the same effect. This is consistent with Savile's interpretation of the flora of the islands near Isachsen. The distribution and behaviour of permanent snow banks in these islands may be of interest.

\section{Movement}

No definite evidence has been found of movement in the ice cap. Surveys were made in 1959, I960 and I96 I using tellurometer and theodolite traversing. The stake network was maintained over the thicker part of the ice cap and another survey has recently been completed by F. P. Hunt of the Polar Continental Shelf Project. One compensation for this presently negative conclusion is that, from the monuments established around the ice cap, the positions of former measured elevations can be recovered should the stakes melt out, and an accurate measurement of thinning of the ice cap over a long period can be made.

\section{Acknowledgements}

This paper is a production of the Glaciology Section, Geographical Branch, of the federal Department of Mines and Technical Surveys, Ottawa. It represents a part of the Geographical Branch's contribution to the Polar Continental Shelf Project, and both the Branch and the author are greatly indebted to Dr. E. F. Roots, Project Coordinator, for his extensive assistance and personal encouragement.

MS. received 4 July 1964 


\section{REFERENCES}

Arnold, K. C., and MacKay, D. K. In press. Different methods of calculating mean daily temperatures, their effects on degree-day totals in the high Arctic, and their significance to glaciology. Geographical Bulletin (Ottawa), No. 21, p. 123-29.

Dunbar, Moira, and Greenaway, K. R. 1956. Arctic Canada from the air. Ottawa, Canada. Defence Research Board.

Hornal, R. Unpublished. Detailed gravity surveys on Ellef Ringnes and Meighen Islands, Queen Elizabeth Islands, Northwest Territories, I96o. [B.Sc. thesis, Queen's University, Kingston, Ontario, 1961.]

MacKay, D. K., and Arnold, K. C. Unpublished. Access to Meighen Island, N.W.T. [MS. completed, 1964.]

Savile, D. B. O. I96r. The botany of the northwestern Queen Elizabeth Islands. Canadian Journal of Botany, Vol. 39, No. 4, p. 909-42.

Stebelsky, I. Unpublished. A microclimatological study in the Canadian Arctic. [B.A. thesis, University of Toronto, 1962.]

Stefansson, V. 1921. The friendly Arctic. New York, Macmillan Co. [New edition, with new material: New York, Macmillan Co., 1943.]

Stefansson, V. 1939. The problem of Meighen Island. Privately printed for Mr. Joseph Robinson, New York.

Thorsteinsson, R. 1961. The history and geology of Meighen Island, Arctic archipelago. Canada. Geological Survey. Bulletin 75 . 